\title{
Research on the Construction of Coal Legal System in the Past 40 Years of the Reform and Opening-up
}

\author{
Mengchen Liu, Shengqiang Yang* \\ School of Safety Engineering, China University of Mining and Technology, Xuzhou, China \\ Email address: \\ 1573737075@qq.com (Mengchen Liu), 453526930@qq.com (Shengqiang Yang) \\ ${ }^{*}$ Corresponding author
}

To cite this article:

Mengchen Liu, Shengqiang Yang. Research on the Construction of Coal Legal System in the Past 40 Years of the Reform and Opening-up. American Journal of Environmental and Resource Economics. Vol. 4, No. 3, 2019, pp. 92-95. doi: 10.11648/j.ajere.20190403.11

Received: May 25, 2019; Accepted: June 28, 2019; Published: July 24, 2019

\begin{abstract}
Since The Reform and Opening-up 40 years ago, China has been committed to the construction of the rule of law in coal industry, Chinese coal legal system has gone through three stages the construction of coal legal system in the initial marketization process, the construction of coal legal system in the period of the initial establishment of socialist market economic system, and the construction of coal legal system in the period of the perfection of market economic system. It can be said that in the past 40 years, great achievements have been made in the construction of coal legal system in China. In the past 40 years, the construction of coal legal system has played an irreplaceable role in protecting occupational safety, preventing and reducing production safety accidents and safeguarding people's lives and property safety. Since the reform and opening up, China's construction of the rule of law in coal has also increased the country's coal production, realized the mechanization of coal production, and provided a strong impetus for China's industrial development. By summarizing the development process of the construction of coal laws, the development direction of the construction of coal legal system in the new era has been pointed out.
\end{abstract}

Keywords: The Reform and Opening-up, 40 Years, Coal, Legal System Construction

\section{Introduction}

The third Plenary session of the 11th CPC Central Committee not only opened the great process of China's reform and opening up, but also opened the great process of the development of the rule of law in China. Over the past 40 years of the Reform and Opening-up, China has not only made great economic and social development, but also made great progress in China's coal industry and the rule of law in coal.

\section{The Rule of Law in Coal in the Initial Marketization Process (1978-1991)}

The Third Plenary Session of the Eleventh Central Committee of the Communist Party of China proposed to "transfer the attention of the people of the whole country to the socialist modernization drive, develop socialist democracy, and improve the socialist legal system." [1] In this context, "the way of governing the country also began to change, from belittling the legal system, denying the rule of law, long-term political movement to focus on the legal system, through the gradual improvement of the democratic legal system, policy and legal system to govern the country together." [2] However, in the early stage of reform and opening up, the economic system was still planned. The energy contradiction was not prominent, and the demand for coal legislation was not strong. At this stage, coal legislation focused on labor protection. In 1978, the Central Committee of the Communist Party of China proposed to strengthen labor protection in the Notice of Seriously Doing a Good Job in Labor Protection. Comrade Deng Xiaoping proposed the formulation of the Labor Law in the closing speech of the Central Working Conference. On April 9, 1979, the State Council made it clear in the report on strengthening Dust Prevention and Drug Prevention in factories and Mining Enterprises issued by the former State Administration of Labor and the former Ministry of Health, new construction projects should conscientiously design, construct and put into production at the same time as the main project, do a good job in design review and completion acceptance, and initially form a "three simultaneous system". Since the early 1980s, the state has changed from a planned 
economic system to a planned socialist commodity economic system, and the number of coal legislation has increased rapidly. at this stage, a national supervision system for coal mine safety has been initially established. Coal safety began to enter the legal track. In 1980, the former Ministry of Coal Industry promulgated the Coal Mine Safety regulations to further strengthen the safety management of the coal industry. On January 1, 1981, the former State Administration of Labor established the Mine Safety Supervision Bureau to implement state supervision on mine safety and health work throughout the country. On February 23, 1982, the State Council issued the Mine Safety Regulations and the Mine Safety Supervision Regulations, which ended the history of "there's no law to rely on" in coal mines, standardized coal mine safety work according to law, and implemented a national safety monitoring system for mines. Since then, the coal legislation process has accelerated. In July 1984, the State Council issued the Decision on Strengthening Dust and Anti-Drug Work. On March 19, 1986, the State Council promulgated the Mineral Resources Law, which determined the three systems of mineral resources exploration and approval, mining license and supervision and management, and played a certain role in regulating mineral resources exploitation activities according to law. In 1987, the State Council promulgated a series of mining management regulations such as the Interim Measures for the Administration of Mineral Resources Exploration and Registration, the Interim Measures for the Management of Mining Registration of Mining Enterprises under the Wholes of the People's Republic of China, and played an important role in ensuring the safe production of coal mines.

\section{Coal Legal Construction During the Initial Establishment of the Socialist Market Economic System (1992-2001)}

With the in-depth development of reform and opening up, the gradual establishment of the socialist market economic system and operational mechanism, coal legislation has become active, and the prototype of the legal system based on the Coal Law has been initially established. The Mine Safety Law, passed on November 7, 1992, "not only clarifies the status, supervision and management mode, and responsibility system of mine safety work under the socialist market economic system, but also becomes the basic preparation for standardizing mine safety work." [3] In December 1994, the State Council promulgated the Measures for the Administration of Coal Production Licenses and the Regulations for the Administration of Township Coal Mines. The promulgation of the two administrative regulations ended the history of no specific coal industry legislation, filling the gap in the lack of coal industry legislation in national legislation. It has created a new era of rule of law in the coal industry. The State Council promulgated and implemented the "Coal Law" in 1996, and the promulgation of the Coal Law was to rationally develop and utilize coal resources, establish normal coal construction, production, safety and coal circulation order, and safeguard the legitimate interests of the coal industry and coal enterprises. With the promulgation of the Coal Law, the coal legal system was initially constructed. Subsequently, the Implementation Regulations of the Mine Safety Law (1996), the Measures for the Administration of Registration of Mineral Resources Exploration and Exploration Blocks (1998), the Measures for the Administration of Mineral Resources Exploitation Registration (1998), and the Management of Exploration Rights and Mining Rights Transfer Measures (1998) and other related regulations have been introduced. These regulations have further strengthened the management of coal exploration, mining and transfer. In 2001, the State Council promulgated the Regulations on the Investigation of Administrative Responsibility for Extraordinary Security Accident, which is of great significance in curbing the occurrence of coal mine accidents and rectifying the market order.

\section{Construction of the Rule of Law in the Period of Perfecting the Market Economy System (2002-Present)}

In November 2002, the 16th National Congress of the Communist Party of China was held, and the market economy system was gradually established and improved. With the rapid development of China's economy, coal demand has increased substantially, and the process of building a rule of law in coal has accelerated. In 2002, the Safe Production Law was promulgated and implemented as the first comprehensive law on safety production management in China. Its introduction marks a new stage in the legalization of China's safe production. After the publication of the Safe Production Law, it has achieved remarkable results in enhancing the public's awareness of the rule of law in public safety, carrying out government safety supervision work, and standardizing enterprise safety production activities. In order to meet the needs of safe production in different periods, the Safe Production Law amendments were made in 2009 and 2014 respectively. In 2004, the State Council promulgated the Implementation Outline for the Comprehensive Promotion of Administration by Law and established the goals and requirements for building a government under the rule of law. In 2005, the State Council issued the Several Opinions on Promoting the Healthy Development of the Coal Industry, researched and formulated the Energy Law, and the Coal Industry Development Policy was officially released. The Mineral Resources Act and the Mine Safety Act were amended in 2009. The Coal Law was revised in 2009, 2011, 2013 and 2016 respectively. In particular, after the revision in 2013, the coal production license and coal business license were cancelled, simplifying the administrative examination and approval matters and processes for coal. Marketization has been further loosened. In order to curb coal mine accidents, the Special Provisions on Preventing Coal Mine Production Safety Accidents (2005), Production Safety Accident Reports and Investigation and Handling Regulations (2007) have been 
promulgated and implemented to make production safety accident reports, investigations and treatments coherent. Administrative Measures for Coal Mine Safety Inspectors (developed in 2003, revised in 2015) regulates the management of coal mine safety inspectors; Administrative Punishment Measures for Coal Mine Safety Supervision (established in 2003, revised in 2015), and Administrative Measures for Coal Mine Safety Supervision Fines (2003) increased penalties for coal mine safety violations; Safety Facilities Supervision Regulations for Coal Mine Construction Projects (established in 2003, revised in 2015), and Implementation Measures for Safety Production Licenses for Coal Mine Enterprises (developed in 2004, 2015 Revision), Coal Mine Water Control Regulations (2009), Coal Mine Leadership Class and Safety Supervision and Inspection Regulations (developed in 2010, revised in 2015), Coal Mine Safety Training Regulations (2012, 2013, 2013) Revised), Critical Standards for Hidden Dangers of Major Production Safety Accidents in Coal Mines (2015), Regulations on Prevention and Control of Occupational Disease Hazards in Coal Mine Workplaces (2015), Safety Training Regulations for Coal Mines (2017), etc. to further standardize the management of coal production, coal mine production safety guarantees to a certain extent.

\section{There Is a Long Way to Go to Perfect the Rule of Law in Coal}

Over the past 40 years of Reform and Opening-up, the coal legal system, with the Coal Law and the production Safety Law as the first, the Mine Safety Law, the Mineral Resources Law and the Coal Mine Safety Supervision regulations as the main force, has been formed and gradually improved. The supervision and supervision system is becoming more and more perfect, which has realized the mining, production and management of coal mine according to law to a certain extent, and ensured the continuous and stable improvement of coal mine safety. From 1978 to 2018 , the national coal production increased from 618 million $\mathrm{t} / \mathrm{a}$ to nearly 3.6 billion $\mathrm{t} / \mathrm{a}$, a net increase of 4.8 times, the number of coal mines decreased from more than 80,000 to less than 5,900, a decrease of $92.6 \%$ or more The number of deaths from coal mine accidents dropped from a maximum of 7,000 to 333, a drop of about 95\%. [4-5] The number of serious accidents dropped from 95 in 1997 to 2 now, down $98 \%$, and the death rate per million tons was 9.71. Dropped to 0.093, down 99\%. [6-7]

\section{Conclusion}

The 40 years of development of the rule of law in coal shows that since the Reform and Opening-up, China's rule of law construction has made remarkable achievements. In the past 40 years of reform and opening up, the rule of law in coal has made great achievements and significant progress, but it still faces many new challenges. First of all, new situations and new institutions have new situations and new problems. In
March 2018, the National Coal Mine Safety Supervision Bureau was managed by the Emergency Management Department. [8-11] In order to meet the needs of institutional reform, it is necessary to strengthen relevant legislation such as emergency disposal and accident rescue; Secondly, in accordance with the actual situation, timely revision of important laws and administrative regulations, such as speeding up the revision of the Coal Law, Mine Safety Law, Coal Mine Safety Supervision Regulations; [12-15] Finally, the current coal mine safety foundation is still weak, and the supervision and supervision law enforcement still needs to be strengthened. It is necessary to gradually improve the supervision and inspection, coal mine training, risk management and control legislation, further strengthen the rule of law in coal mines, and continue to contribute to ensuring national energy security and the healthy development of the national economy.

\section{References}

[1] Jiang Ming 'an. Three Leaps: The Process of Rule of Law Development in China during the 40 Years of Reform and Opening up [N]. Legal Daily, 2018-9-12.

[2] Guangyi Liu. Creating a New Situation of Safe Coal Mining [J]. Labor protection, 1993 (9).

[3] Feng Bo. The perfect operation mechanism of China's coal mines [J]. China Coal, 1995 (8).

[4] Shaohua Shi. Overburden damage height of fully mechanized caving mining in extra-thick coal seam [M]. Beijing: Coal Industry Press, 2011.

[5] Wang Sen 'hao. Create a new era of legal construction in the coal industry [J]. China Coal, 1996 (10).

[6] Huang Yi. The sword of coal mine safety supervision --Congratulations Execution of the Ordinance $[\mathrm{J}]$. Coal Economic Research, 2000 (11).

[7] Rong 'zhenYe. Retrospect and Prospect: China's Energy Law System Construction since Reform and Opening up [J]. Journal of Zhengzhou University (Philosophy and Social Sciences Edition), 2009 (5).

[8] Wang Feng, Impact of Coal Safety Regulations on National Coal Production [J]. China Mining Industry, 2018 (9).

[9] Wenzong Peng; Jiaxing Wu; Wenjing Dong; Analysis on the Elimination of Labor Disputes in China's Coal Enterprises [J]; Taxation; No. 14, 2018.

[10] Ruihua Zhang; Large Coal Enterprises Pay Attention to Professional Talents [N]; China Coal Daily; 2019.

[11] Quanzhou Zhao; Promoting the strategy of "strengthening enterprises by talents" to provide talent guarantee for better and faster development of Jilin coal industry [N]; Jilin Daily; 2008.

[12] Liu Hongren; Let technical talents become "fragrant baboons" [N]; China Coal Daily; 2019.

[13] Qiongjie Wang; Why Talents Talk about Coal Attitudes Change [N]; China Mining News; 2018. 
[14] Desheng $\mathrm{Hu}$; The qualitative orientation of the proposed Energy Law [J]; Journal of Jiangxi University of Science and Technology; No. 06, 2015.
[15] Jianxun Li; Chunlin Yuan; Investigation of China's Coal Talent Crisis [N]; Shanxi Daily; 2017. 